\title{
Good Faith and the Fair Work Act: Its Potential, in Light of the New Zealand Experience
}

\section{Shaunnagh Dorsett * George Lafferty **}

\section{Abstract}

This article addresses the potential of the Fair Work Act's good faith bargaining provision to enhance good faith bargaining and employment relationships, using New Zealand's good faith provisions under the Employment Relations Act 2000 as a comparative frame of reference. It explores the limitations of the Fair Work Act's compliance-based approach to good faith, which consists mainly of the parties presenting a legally defensible appearance of not acting in bad faith. In contrast, the New Zealand legislation aims to suffuse good faith with considerable content and definition, enabling parties to the employment relationship to extend good faith well beyond bargaining. In contrast to the Employment Relations Act, the formalistic, procedural approach promoted by the Fair Work Act is unlikely to encourage a significant cultural change towards meaningful good faith principles and practices.

\section{Keywords}

Australian workplace relations; Fair Work Act Australia; good faith; labour law; unionmanagement relations; New Zealand workplace relations.

\section{Introduction}

The Australian Fair Work Act 2009 (Cth) reintroduced a statutory requirement of good faith bargaining, after a formal absence of over a decade. In this article, we assess the potential of this provision to expand good faith practices in both collective bargaining and broader employment relationships, drawing on the New Zealand experience of good faith under that country's Employment Relations Act 2000 to inform our discussion. New Zealand not only has close historical and economic ties with Australia; it also possessed until 1990 a very similar industrial relations system, although the two countries subsequently diverged during the 1990s. With the National Party government's Employment Contracts Act 1991, New Zealand's conciliation and arbitration system was rapidly dismantled,

\footnotetext{
* Faculty of Law, University of Technology, Sydney

** School of Management, University of Western Sydney
} 
whereas Australia followed a more measured path towards decentralisation of its industrial relations.

Yet Australian unions following the election of the Rudd ALP government in November 2007 were in a position comparable to that faced by New Zealand unions at the election of Helen Clark's Labour-led government in November 1999. The respective labour movements in the two countries were emerging from lengthy periods of right-wing government and anti-union legislation. Neither situation appeared to offer particularly fertile ground for the promulgation of good faith principles and practices.

We suggest here that, despite the context within which New Zealand's Employment Relations Act was introduced, its good faith provisions have encouraged significant improvements in collective bargaining and employment relationships. Focusing on the period from when the Act came into force until the Labour Party's loss of government in November 2008, we explore what insights the New Zealand experience may afford for good faith within the Australian context. To inform our discussion, we draw on several sources: detailed interviews conducted with sixteen senior union officials; a series of annual surveys conducted between June 2004 and June 2008 of New Zealand collective agreements; plus published and unpublished material compiled by New Zealand's Department of Labor, on the perceptions of employers, unions and employees of the impact of the Employment Relations. These sources are used to assess how knowledge of the New Zealand experience may assist in the development of good faith in employment relationships within the Australian context.

\section{Good Faith: A Compliance-Based Approach}

There is nothing new or particularly innovative about good faith provisions in bargaining, either in Australia or internationally. Most notably, the United States has a lengthy and extensive history, institutional frameworks and case law on good faith in collective bargaining processes, with extensive discussion of employer resistance to the duty of good faith (for example, Cox 1958; Duvin 1964; Rathmell 2008; Cooper and Ellem 2009). Nor is the Fair Work Act the only legal context in which good faith is the standard by which behaviour is judged: mortgagees exercising a power of sale, company directors and those performing contractual obligations are also legally required to act in good faith. Even more importantly with respect to this paper's focus, the Fair Work Act is not the only Act in which good faith obligations are imposed on parties negotiating. Section 31(1)(b) of the Native Title Act 1993 (Cth) mandates that negotiations under that Act be undertaken in 'good faith'.

From March 1994 to December 1996, s 170QK of the Industrial Relations Act 1988 contained specific provisions giving the Australian Industrial Relations Commission (AIRC) the power to issue good faith bargaining orders, which were intended to assist negotiations that had already commenced (see Rathmell 2008) However, there was no enforceable requirement in the Act to bargain in good faith. Even this small encroachment of good faith into the bargaining arena was removed by the Howard Coalition Government in 1996, leaving only a residual power for the AIRC to suspend or terminate the bargaining period if the parties 
had not 'genuinely tried to reach agreement' before taking protected industrial action (s 170MW(2)). While some decisions before the Commission likened this to an implicit good faith requirement, this was by no means a universal opinion (Lee 2005: 28-30).

McCallum (2000: 225) has suggested that the absence of good faith provisions after 1996 shifted the balance towards employers, not least because the absence of union recognition in bargaining, an integral component of good faith bargaining, allowed employers to move increasingly to individualised processes. Consequently the return of a statutory requirement of good faith into the bargaining process is to be welcomed. However, while good faith has been re-injected into the bargaining process it remains limited to the bargaining context, and the Act takes what is essentially a compliance-based approach. This is, for example, in direct contrast to what might be termed the 'relationship-based' approach of New Zealand's Employment Relations Act 2000, in which good faith is placed at the centre of the employment relationship, rather than being restricted to bargaining and to the bargaining period.

Section 228 Fair Work Act 2009 comes close to imposing a requirement that parties must bargain in good faith, although the provisions remain largely procedural in nature. Section 228 (Cth) sets out the good faith requirements that must be met during bargaining. It adopts a basically procedural approach oriented around bargaining protocols, which include attendance at meetings, disclosure of relevant information and responding to proposals. Arguably the most important provision is s $228(1)(\mathrm{f})$, which requires that the parties recognise and bargain with all other bargaining representatives. The only potentially substantive requirement is the obligation on parties to refrain from capricious or unfair conduct that undermines freedom of association or collective bargaining (s 228(1)(e)). This is a catch-all provision, one which the Explanatory Memorandum suggests is intended 'to cover a broad range of conduct'. Examples of conduct that would constitute a breach of the good faith requirements include: failing to recognise a bargaining representative; dismissing engaging in detrimental conduct or an employee because they are a bargaining representative; preventing an employee from appointing their own representative (House of Representatives 2008: 149).

The most glaring deficiency with each of these provisions is that they provide no substantive content to the principle of good faith, however that may be defined. As in the United States (Cooper and Ellem 2009), good faith bargaining is thus deemed to be ensured by compliance with procedural requirements. The Act, however, does not require genuine good faith bargaining, in the sense of genuinely working towards an agreement or not undermining attempts to reach such an agreement - other than by failing to comply with the formal protocols of the bargaining process, such as attendance at meetings. Perhaps most telling is the Federal Government's own statement that while good faith provisions exist in Queensland and Western Australia they 'do not impose onerous additional obligations on employers' (House of Representatives 2008: xlii). Bargaining orders are available if a representative is concerned that the other side is not meeting the good faith bargaining provisions (s229(4)). If a bargaining order is 
made, it can include actions or requirements to ensure the good faith bargaining provisions are adhered to (s 231(1)). Bargaining orders or determinations of bargaining disputes are, however, a last resort remedy (House of Representatives 2008: paras [971], [1088]). The Explanatory Memorandum notes that few orders or determinations have actually been applied for in Western Australia or Queensland. However, in the new context of the Fair Work Act a number of applications based on alleged breaches of good faith have already been made to the national employment relations tribunal, Fair Work Australia, and it is trite to note that the utility of these provisions ultimately will depend on how they are interpreted, both by Fair Work Australia and the courts. (For a partial list of Fair Work Australia determinations and discussion see Cooper and Ellem 2009.)

Like the Wagner Act in the United States (National Labour Relations Act 1935), the provisions of the Fair Work Act limit good faith to a procedural context - good faith bargaining (or at least the outward signs of it) can be achieved through a range of conduct in bargaining. It is process, and the appearance of it, rather than outcomes, on which the Fair Work Act is focused. As Rathmell outlines, good faith - or perhaps more accurately bad faith - is a relatively clear concept in the US context: refusing to confer with other parties; unilateral changes to conditions; bypassing bargaining representatives; and like activities (for a comprehensive list see Rathmell 2008: 173; see also Cooper and Ellem 2009). In orientation this is not dissimilar from the s 228 list. Good faith bargaining is defined in terms of attending meetings, disclosing information, responding to proposals and giving genuine consideration to proposals. It is not a requirement to make concessions or to conclude an agreement. Good faith, then, largely consists of presenting a legally defensible appearance of not acting in bad faith when implemented within a procedural framework such as that of the Wagner Act, the Fair Work Act or even the Native Title Act.

The Native Title Act presents a significant, and generally ignored, site of comparison to the Fair Work Act. Like the Fair Work Act and indeed the Wagner Act, the requirement of good faith is lodged within a context of bargaining, and is focused on process not outcomes. Section 31(1)(b) is part of the future act provisions, which provide that native title holders and registered claimants have limited procedural rights with respect to proposed valid future activities on their lands (for a definition see s 233). Parties must bargain about conditions on which the future act (for example, mining) can occur. Specifically, the provision requires that the parties must negotiate in good faith with a view to obtaining the agreement of each of the native title parties to (i) the doing of the act; or (ii) the doing of the act subject to conditions to be complied with by any of the parties. Unlike in the Fair Work Act, or even the Wagner Act, there is provision for a determination by the relevant tribunal, in this case the National Native Title Tribunal, if no decision can be reached by the parties after six months of negotiation. Notably, however, this can only occur if the Tribunal is satisfied that the parties have negotiated in good faith (s 36(2)). Like the Fair Work Act, the Native Title Act does not define good faith. Rather, it is yet again negative: good faith negotiation is negotiation which has not occurred in bad faith (Burnside 2009: 4). Perhaps unsurprisingly, therefore, the development of good faith 
under the Native Title Act has parallels to the Wagner Act. Through case law a series of indicia of bad faith have developed, known as the Njamal indicia, and which similarly focus on a range of process matters such as attending meetings, appropriate communication, and a tendency to shift position. While there is an overall standard of acting 'honestly and reasonably' in bargaining conduct (Gulliver Productions $v$ Western Desert Aboriginal Corporation (2005) 96 FLR 52), over time this has become, as with Wagner jurisprudence, a lengthy list of specific conducts which indicate bad faith (for a full list see Western Australia $v$ Taylor (1996) 134 FLR 211).

As Burnside relates, this can, unsurprisingly, result in 'window dressing, whereby parties treat the requirements as formalistic. Generally, however, the Tribunal has looked below the surface in order to determine whether negotiations have proceeded in good faith (Burnside 2009: 10). Nevertheless, it is possible to simply comply with all the procedural steps and thereby be seen to be acting in good faith. While parties cannot be completely passive, in order to fall foul of the good faith provisions Burnside suggests that 'extreme behaviour' might be needed (Burnside 2009: 11). The result of this approach to good faith has been that in the native title context, good faith is largely dealt with through effective bargaining protocols. Within this arena, good faith is a compliance model. The failure to specify that parties must negotiate in good faith towards an agreement has significantly limited the scope of the good faith provisions. A recent Federal Court decision determined that as a result parties do not need to have reached any particular stage in negotiations prior to applying to the Tribunal for a determination and in so doing rejected the argument that negotiations ought to be substantive (FMG Pilbara Pty Ltd v Cox [2009] FCAFC 49). As a result of this, and a growing concern that negotiations are 'characterised by the absence - rather than the presence - of good faith' (Attorney-General 2008), the Government intends to amend the act to clarify requirements of good faith (Attorney-General 2010). Whether this will move beyond a re-embedding of the compliance-based approach seems unlikely and, given that the indicia are already present in case law, this raises further questions as to whether this approach will ultimately succeed.

\section{Good Faith: The Relationship-Based Model}

What then is the alternative? By contrast to the Australian compliance-based approach, the New Zealand legislation gives good faith considerable content and greater definition - or, perhaps more accurately, indications as to how the parties can produce their own contextually-specific understandings. The good faith obligation also extends beyond bargaining, suffusing the full range of employment relationships. The section 4(1) obligation states that 'the parties to an employment relationship ... must deal with each other in good faith' (s 4(1)(a)). Subsection 1A further specifies that: 'The duty of good faith in subsection (1)

a. is wider in scope than the implied mutual obligations of trust and confidence; and 
b. requires the parties to an employment relationship to be active and constructive in establishing and maintaining a productive employment relationship in which the parties are, among other things, responsive and communicative...'?

Employment relationships, then, are conceived both broadly and deeply — and this characteristic is one of the keys to the good faith provisions. Good faith extends beyond employer-employee relationships, to unions and their members, as well as, in certain situations, unions and members of other unions, or even employers and other employers - for example, during negotiations for multi-employer collective agreements (MECAs). The Act lists no fewer than eight distinctive types of employer relationships in s 4(2). In addition, examples of contexts in which the obligation applies are given, thereby demonstrating the way in which the good faith obligation applies to all these employment relationships. According to the Act, good faith includes, but is not limited to, bargaining, matters relating to collective agreements while in force, redundancies, union access to workplaces, communication, changes to business, and contracting out (s 4(4)).

Within the bargaining context itself, s 32 (the counterpart New Zealand provision to the Fair Work Act's s 228) also imposes broader obligations. ${ }^{2}$ Section 32 imposes a minimum set of actions that must be undertaken, including the requirement in s $32(\mathrm{ca})$ that 'even though the union and the employer have come to a standstill or reached a deadlock about a matter, they must continue to bargain ... about any other matters on which they have not reached agreement'. Most importantly, s 33 states that the obligation of good faith 'requires a union and an employer bargaining for a collective agreement to conclude a collective agreement unless there is a genuine reason, based on reasonable grounds, not to.' A genuine reason does not include opposition or objection in principle to bargaining for, or being a party to, a collective agreement (33(2)(a)) (on interpretation of these provisions see Anderson 2006).

Since 2004, following a series of amendments to be discussed later in this paper, the New Zealand Act has specifically provided for a penalty for breach of good faith where the breach is 'deliberate, serious and sustained' (s 4A(a). There is also a specific subsection providing for penalties where the breach is intended to undermine collective bargaining (s $4 \mathrm{~A}(\mathrm{~b})$ ) - the former requires a higher threshold than the latter. None of this is to say that good faith overrides managerial prerogative, but the provisions nonetheless indicated a significant shift in legislative intent from the Employment Relations Act's neo-liberal predecessor, the Employment Contracts Act, which was noted for its virtual exclusion of unions.

The Employment Relations Act also provides for the development of codes of conduct in relation to good faith in bargaining. Codes are intended to provide guidance about the application of the duty of good faith in relation to collective bargaining (s 35(3)) and are developed by committees established under the Act, comprised of at least one person representing unions, one person representing employers' groups and one person appointed by the Minister in her or his discretion (s 36(1)). The code is relatively brief and sets out procedural requirements for bargaining. While this is little more than a list giving more direction to the 
basic requirements of s 32 (available on the Department of Labour's website), it is potentially helpful for smaller employers. This comparison, then, illustrates the limited nature of the Fair Work Act's good faith provisions, which apply only to the actual bargaining process and are procedural in nature.

\section{Good Faith as Concept and Practice: Possibilities, Hazards and Risk}

During the early years of New Zealand's Employment Relations Act, there was undoubted confusion among the parties concerning interpretations of good faith within the bargaining process. Nonetheless, there was evidence of its positive impact on bargaining cultures, as observed by a senior official of one major union:

And I think during the first couple of years there was, certainly in our industry, a fair bit of respect shown towards the good faith stuff, not that anybody really knew what it meant, but okay so we took it on and we talked nicely to each other and we went back the table more often than we might have (Personal interview, July 2007).

In this respect, the absence of a single, uncomplicated understanding of good faith may assist the integration of good faith within employment relationships, since it allows the parties to develop their own understandings and practices that are specific to particular settings.

Alternatively, though, this openness can lead to less constructive outcomes - for example, where employers have used non-union, individual agreements to undermine the bargaining process - a complaint made by several union leaders:

What I suppose is the frustration is that what you assumed might be useful about good faith is completely undefined. And therefore employers are now making it up, in my view. And this is a significant difference between us. Unions again, because of our resource base, we have to react extremely pragmatically about what we tolerate from the boys and what we don't.... So the classic is the offer to the individuals where every employer has done this to us since 2002, at one stage or another in a dispute, come out and made the offer to individuals and we suffer huge membership loss as a result. In [one] dispute we increased our membership by about twenty per cent in the four months leading up to the bargaining. In the two weeks afterwards they came out and offered the individuals the deal that we'd rejected. We lost four hundred members (Personal interview, July 2007).

Therefore, the practical implementation of good faith incorporates a considerable degree of risk for all parties: as in the above case, the long-term establishment and maintenance of mutual trust may be sacrificed in favour of short-term tactical expediency. Yet embracing this degree of risk is integral to the development of greater long-term openness, transparency and trust.

The problems often posed by the lack of consistent, mutual understandings of good faith were addressed during the early years of the Employment Relations 
Act. In 2003, the government's Review of the Act's operation drew the conclusion that the standard of good faith in employment relationships had fallen short of the expectations raised by the Act (see Walker 2007). The government's response was to introduce measures to strengthen support for collective bargaining and good faith. Despite protracted opposition from employer organisations and their parliamentary supporters, the Employment Relations Amendment Act (No. 2) came into effect from December 2004. The amendments were designed to reinforce good faith in practice, particularly by restricting the ability of employers to undermine collective bargaining. The provisions included: prohibition of employers discouraging employees from participation in collection bargaining or being covered by a collective agreement; a requirement for employers and unions who have reached an impasse on one issue to continue bargaining on other issues; the stipulation that collective bargaining must lead to a collective agreement unless there are 'genuine reasons' based on 'reasonable grounds' preventing it. 'Reasonable grounds' could not include in-principle opposition to collective bargaining or collective agreements. A breach of good faith is possible only where the employer has deliberately sought to undermine the bargaining process or the collective agreement.

In Australia, under the Fair Work Act (s 174) an employee can nominate a bargaining agent other than a union to represent them - like the New Zealand Employment Relations Act's neo-liberal predecessor, the Employment Contracts Act 1991. In contrast, the Employment Relations Act permitted only registered unions to bargain for a collective agreement and only on behalf of the membership of their union. A collective agreement could cover only members of a union which was a party to the agreement. Under the Employment Relations Act, new employees appointed to a position covered by a collective agreement were given two main options:

1. if they belonged to or joined a union that was a party to the collective agreement and it covered their position, they were then covered by the collective agreement;

2. if they were in a position covered by a collective agreement and they did not belong to or join a union that was a party to the agreement, they were employed on an individual agreement with the terms and conditions of the collective agreement for the first 30 days, at the end of which period, if they have not joined the relevant union, the employee's terms and conditions can be varied from the collective agreement's terms and conditions.

By granting registered unions exclusive rights to conduct collective bargaining, therefore, the Employment Relations Act formally excluded one impediment to good faith collective bargaining that remains in the Fair Work Act: the possibility that non-union bargaining agents could undermine collective bargaining processes - although collective bargaining still continued to be undermined in practice (most commonly through free-riding and employer resistance to collective bargaining).

Following the December 2004 Amendments to the Employment Relations Act, passing on of union-negotiated pay and conditions to employees on individual 
agreements was explicitly prohibited. To address the 'free rider' issue, a provision was introduced to allow bargaining fees, whereby non-union employees could be covered by a union-negotiated collective agreement. This could occur, however, only if both employers and unions agreed to the inclusion of a bargaining fee arrangement within the collective agreement. Non-union employees were also enabled to opt out of the bargaining fee, leaving them to negotiate their own individual terms and conditions. The Amendments also strengthened good faith provisions with respect to individual employment agreements, which must be based on genuine individual bargaining.

Informal passing on continues, however, as indicated by extensive anecdotal evidence. In the words of one senior manager in a large public sector organisation observed, 'It's just not possible for us to bargain individually with every non-union person.' Also, our surveys during the period 2004-2008 indicated that in most collectivised workplaces the collective agreement set the terms and conditions for almost all employees, regardless of their union membership status (Lafferty and Kiely 2008: 14). Yet, despite the persistence of informal free-riding, the 2004 amendments to the Employment Relations Act constituted a significant statement of principle: they provided an explicit acknowledgement that passing on undermines good faith bargaining. More rigorous enforcement of the legislative ban on passing on, including a requirement for employers to demonstrate genuine individual bargaining, could - conceivably - eliminate free-riding with respect to collective bargaining in New Zealand.

The Fair Work Act, by contrast, lacks even a formal legislative discouragement of free-riding: both the passing on of union terms and conditions and the ability of employers to conduct ballots for collective agreements that sidestep a relevant union are significant ongoing impediments to good faith bargaining and relationships. Under the Fair Work Act, then, passing on remains integral to the bargaining process, leaving avenues for not only employers and unions but also for non-union employees in unionised workplaces to circumvent substantive good faith (most importantly, through support for a non-union enterprise bargaining agreement) while maintaining compliance with the legislation's good faith bargaining requirements. Employers can propose a non-union collective agreement to employees and non-union employees can vote for a collective agreement that may undermine the relevant union's bargaining position.

Whereas the good faith principle in the Fair Work Act is limited to bargaining, the development of good faith employment relationships is the defining characteristic of the Employment Relations Act, a feature reinforced by the 2004 amendments. The most salient revisions to the original Act (with new wording italicised) were as follows:

- to build productive employment relationships through the promotion of muttral trust and confidence-good faith in all aspects of the environment and of the employment relationship;

- (ii) by reeognising that employment relationships nutrs be built on good faith behaviour; 
- (ii) by recognising that employment relationships must be built not only on the implied mutual obligations of trust and confidence, but also on a legislative requirement for good faith behaviour; and

- (iii) by acknowledging and addressing the inherent inequality of bargaining power in employment relationships;...

Particularly significant is the elimination of the single word 'bargaining' before 'power,' denoting the recognition of the power inequality in employment relationships generally, thereby extending it well beyond the scope of bargaining and of the main traditional role of unions as bargaining agents. The contrast with the limited expression of good faith in the Fair Work Act is unmistakeable.

A critical feature of the Employment Relations Act has been its recognition of the power imbalance between employer and employee. From this recognition flows the need to pursue steps to at least moderate that imbalance - for example, the Act's provision for Employment Relations Education Leave for union members (s 70). The absence of any explicit acknowledgment in the Fair Work Act of the power imbalance inherent to almost all employment relationships perpetuates the fiction celebrated in WorkChoices, of equality in employment relationships. Nor are unions themselves able to compete on equal terms with many larger employers, if disputes over good faith are taken to the courts. As the leader of one prominent New Zealand union lamented, when faced with employer allegations of union bad faith:

If you want to actually try and test any of the good faith provisions then unions just don't have the capacity to do that. This is the outcome of our [company name] dispute which I got the day before Christmas.... These are the allegations of our breaches of good faith that are now going to the [Employment Relations Authority] for testing. So if we're to defend that properly - that's a hundred thousand dollar court case for us and weve got two million bucks in the bank. So that puts it in perspective (Personal interview, July 2007).

The power imbalance between even larger unions and large employers is, therefore, brought into stark relief where unions are faces with litigation. There are substantial reasons for both employees and unions to seek a broader understanding of good faith which reduces the possibility of litigation.

Employer groups have consistently opposed such aspects of the Employment Relations Act as the 'union monopoly' over collective bargaining, the assumption of unequal power between employer and employee, and the requirement for employers to negotiate in good faith towards a collective agreement. (see, for example, Knowles 2003). The vehemence of the employer opposition to both the original Employment Relations Act and its amended version underscores how the legislation threatened the managerial prerogative and individualised employment relations that had proliferated during the Employment Contracts Act period. It also illustrates the direction in which the Fair Work Act's good faith provision may be strengthened towards giving the good faith principle greater force in Australian workplaces. 


\section{Good Faith Relationships and Multi-Party Bargaining}

While the Fair Work Act contains limited provisions for multi-enterprise agreements, the Employment Relations Act introduced provisions to support multiemployer bargaining as a general goal. There was a steady increase for several years in the proportion of employees covered by a multi-employer collective agreement (MECA), reaching a peak in 2007 when MECAs accounted for 33 per cent of all employees covered by collective agreements, but then declining (Lafferty and Kiely 2008: table 3). With respect to this paper's focus on good faith relationships, however, multi-employer bargaining can present significant complications, which may outweigh any proposed benefits (such as consistency of pay and conditions across an industry) of multi-employer agreements.

Moreover, as several of our union interviewees observed, the presence of multiple unions, often in competition with one another, could be a significant impediment to good faith in practice. The practical complexities and difficulties presented by multi-employer and multi-union bargaining are underscored by the tiny proportion of New Zealand employees covered by multi-employer, multi-union agreements: only one per cent of the collectivised workforce (or 0.2 per cent of the overall workforce) (Lafferty and Kiely 2008: table 3). Union representatives interviewed by the Department of Labour saw very limited benefits in multi-union bargaining, preferring informal cooperation to formal joint bargaining, although unions operating as a single bargaining unit could prevent unions being played off against one another:

If it's another union in the industry and we're bargaining together, it makes much more sense because there's no possibility of us undermining each other if we're at the table at the same time arguing, advocating for the same members, for the whole group of members, it's much more advantageous for us (Department of Labour 2009).

Some employers also saw union efforts to enforce MECA bargaining as threatening more constructive approaches. While information disclosure has not been a major impediment to good faith bargaining in single-employer settings, it has been a substantial source of difficulty in multi-employer negotiations (Department of Labour 2009: 35-36).

The presence of multiple unions and/or employers in the bargaining context creates a more hazardous environment for good faith, permitting an employer and/or a union to undercut the bargaining process being conducted by others. Most commonly, employers can claim (with varying degrees of plausibility) that they are in competition with other employers and that the negotiation of a multi-employer agreement undermines their market competitiveness. As one union leader saw it:

They [major company] did try the "we can't afford it" one. And then they backed off a bit because we said "That's great, thank you, we'll test that in court, shall we?". And then "Oh no, that's not what we meant". And now they do the competitive market one. So we can't afford to step out of line with or from [competitor company] this year, we can't give you any more 'cause we've exceeded our budget. Whose budget? Our budget. 
From where? Australia. So we're not bargaining with people who can make decisions? Of course you are. Right, OK, so you're bargaining with us in good faith? Absolutely, that's why we're telling you we can't give you any more because we've exceeded our budget. So with these people it's just a constant evolution of finding the way around it, finding the reason, finding the you know. Bottom line is it's a load of shit, I mean [the competitor company] made $\$ 680$ million last year, what we wanted in terms of a pay claim and what they offered this year, the difference was I think about \$6 million (Personal interview, July 2007).

Even in the New Zealand health sector, which has arguably seen the greatest advances towards good faith employment relationships, the difficulties of multiparty bargaining have become evident.

The health sector has gone a considerable way to embedding good faith in employment relationships through integrating the respective goals of the parties (for example, higher wages and increased funding for public health) within broader societal goals. The 2007 Health Sector Relationship Agreement (Ministry of Health et al 2007) illustrates how good faith principles might be embedded in industryspecific good faith codes and collective agreements. Particularly significant has been the combination of tripartite and bipartite relationships that underpinned this agreement. Building on the 2003 Health Sector Tripartite Steering Group - a Framework for Constructive Engagement, the Health Sector Code of Good Faith (2004) was developed, in conjunction with a series of workshops directed to the strengthening or establishment of workplace consultative committees (2007: 2). A tripartite framework was thereby constructed around good faith principles. This permitted the pursuit of employment issues, including bargaining, within the common goal of improving the national health system. The practical implementation of good faith principles, then, has been facilitated by the progressive construction of negotiated frameworks and employment cultures that create a terrain for issues to be addressed openly by the parties.

However, experiences in the health sector also exemplify how problems may arise from the involvement of multiple parties. According to both the Department of Labour survey and our interviews, the benefits of its Code of Good Faith (included as a Schedule in the Employment Relations Act) have been less than anticipated. The pursuit of good faith practices has been undermined to a considerable extent by the inclusion of private contractors in the multi-employer bargaining process. Despite good faith relationships between employer representatives and unions, employer representatives in competition with each other often exhibited little good faith between one another (Department of Labour 2009: 31). The involvement of further parties, operating according to different principles and goals, therefore compounds the risk of substantive bad faith. Clearly, then, the parties to any bargaining process need to weigh up carefully the potential benefits and disadvantages of multi-party negotiations, with respect to longer-term employment relationships.

Overall, the New Zealand experience suggests that outcomes from the promulgation of good faith principles are unlikely to be immediate or dramatic, but that they can be of enduring value in effecting cultural change. There are factors 
that appear to contribute to greater good faith in employment relationships and in collective bargaining. These include: a single employer and a single union; ongoing relationships that are not confined to bargaining periods, and the presence of meaningful consultation and decision-making mechanisms, both direct (employer-employee) and indirect (employer-union) - this latter observation echoes findings from overseas on the need for a variety of voice mechanisms in contemporary workplaces (see, for example, Freeman, Boxall and Haynes 2007). Given the often contested nature of good faith as both principle and practice, industry-specific codes of conduct with negotiated rules and principles may provide a considerable step forward in achieving mutually accepted understandings of good faith within specific industry contexts. Such an environment can create a context within which good faith becomes the default position: Why act in bad faith when good faith is the simpler, less arduous option?

\section{Conclusion: Good Faith in Principle and Future Practice}

At the beginning of this paper, we said that we were examining a single aspect of the Fair Work Act: good faith. Yet good faith, like any other provision, can be understood adequately only within the context of other provisions (for example, encouragement for multi-employer bargaining) and specific socioeconomic conditions (for example, the prevailing labour market within a particular industry or occupation). Good faith with respect to employment relationships, therefore, is not a static concept - and 'defining' good faith is an unavoidably contentious exercise. Yet, despite this elusive, almost nebulous conceptual quality, the embedding of good faith within employment relationships can provide it with considerable practical substance. The New Zealand experience indicates the considerable potential offered by good faith to the improvement of employment relationships - despite various impediments, including the persistence of free-riding and the difficulties presented by multi-party bargaining.

It would be naïve, or arguably disingenuous, to assume a direct causal link between New Zealand's good faith provisions and the emergence of more open, transparent and consultative employment relationships. There is indeed evidence (McAndrew and Penn 2003; McAndrew 2006) that improvements in bargaining style preceded the Employment Relations Act. Some employers, such as the public service, had adopted more sophisticated, less adversarial approaches during the latter years of the Employment Contracts Act period. Employer-union relationships had become broader and more continuous, rather than being confined to bargaining periods. Nonetheless, good faith bargaining relationships in New Zealand have become considerably more widespread, increasing trust and reinforcing long-term relationships - and much of the credit for this shift has been attributed to the Act (Department of Labour 2009: 30).

As we have indicated in this paper, legislation is not essential to the achievement of such outcomes and legislative provisions that encourage litigious approaches may even impede them. While neither new nor radical, the permeation of good faith principles throughout all levels of the employment relationship can effect profound cultural change. Such change is multi-faceted and often difficult 
to articulate, as acknowledged by several of our interviewees in referring to a different 'atmosphere' or 'climate'.

There have no doubt been some promising recent signs in Australia with respect to the parties developing good faith practices - for example, the agreement on a 'Productive Working Relationship' negotiated by Telstra, the ACTU and three communications industry unions (Telstra-ACTU 2009), although this remains largely protocol-based. Yet the Fair Work Act's good faith bargaining requirement would seem to give minimal encouragement to the permeation of good faith principles throughout Australian workplaces. In short, the Fair Work Act's contribution to changing workplace cultures is likely to be slight, unless employers, unions and employees (including non-unionised employees) use these principles as a basis from which to construct more expansive interpretations of good faith in practice.

\section{Notes}

1. 4(1A) was inserted, on 1 December 2004, by s 5(1) Employment Relations Amendment Act (No 2) 2004. See Coutts Cars Ltd v Baguley [2002] 2 NZLR 533 (CA).

2. For the relationship between sections 4 and 32 see Christchurch CC $v$ Southern Local Government Officers Union [2007] 2 NZLR 614 (CA). According to the Court of Appeal s 32 modifies s 4 where there is an inconsistency between the generalised provision of $s 4$ and the specific provisions of $s 32$. To the extent they are not inconsistent, $s 4$ continues to apply in a bargaining situation (para 31).

\section{References}

Anderson, G. (2006) 'Transplanting and growing good faith in New Zealand labour law', Australian Journal of Labour Law, 19(1), pp. 1-29.

Attorney-General and Minister for Families, Housing, Community Services and Indigenous Affairs (2010) Discussion paper: Leading practice agreements: maximising outcomes from native title benefits, available: http://www. ag.gov.au/www/agd/agd.nsf/Page/Indigenouslawandnativetitle_Nativetitle_ Nativetitlereform\#governance [accessed 1August 2010].

Burnside, S. (2009) Negotiation in good faith under the Native Title Act: A critical analysis', Land, Rights, Laws: Issues in Native Title, 4(3), pp. 1-16.

Cooper, R., and Ellem, B. (2009) 'Fair Work and the re-regulation of collective bargaining', Australian Journal of Labour Law, 22(3), pp. 284-305.

Cox, A. (1958) 'The duty to bargain in good faith', Harvard Law Review, 71(8), pp. 1401-1442.

Department of Labour (2009) The Effect of the Employment Relations Act 2000 on Collective Bargaining, Department of Labour, Wellington.

Duvin, R. P. (1964) 'The duty to bargain: Law in search of policy', Columbia Law Review, 64, pp. 248-292.

Freeman, R., Boxall, P. and Haynes, P. (eds) (2007) What Workers Say: Employee Voice in the Anglo-American Workplace, ILR Press, Ithaca and London. 
House of Representatives (2008) Explanatory Memorandum, Fair Work Bill, Parliament of the Commonwealth of Australia, Canberra.

Knowles, A. (2003) Reviewing the Employment Relations Act, Business New Zealand, Wellington.

Lafferty, G. and Kiely, P. (2008) Employment Agreements: Bargaining Trends and Employment Law 15, Industrial Relations Centre, Wellington.

Lee, M. (2005) 'Crafting remedies for bad faith bargaining, coercion and duress: "Relative ethical flexibility" in the twenty-first century', Australian Journal of Labour Law, 18(1), pp. 26-52.

McAndrew, I. (2006) 'Employers, unions and workplace partnerships in New Zealand', New Zealand Journal of Employment Relations, 31(3), pp. 51-65.

McAndrew, I. and Penn, S (2003) 'Collective bargaining under the ERA 2000: Report of a workshop on negotiation', New Zealand Journal of Industrial Relations, 28(2), pp. 170-182.

McCallum, R. (2000) 'Trade union recognition and Australia's neo-liberal voluntary bargaining law', Relations Industrielles/Industrial Relations, 57(2), pp. 225-251.

McClelland, R. (Attorney-General) (2008) Speech at the Negotiating Native Title Forum, Brisbane, available: http://www.attorneygeneral.gov.au/www/ministers/ mcclelland.nsf/Page/Speeches_2008_FirstQuarter_29February2008-Negotiat ingNativeTitleForum [accessed 1 August 2010].

Ministry of Health, District Health Boards, New Zealand Council of Trade Unions (with health sector unions) (2007) Health Sector Relationship Agreement,Ministry of Health, Wellington.

Rathmell, A. (2008) 'Collective bargaining after WorkChoices: Will "good faith" take us forward with fairness?', Australian Journal of Labour Law, 21(2), pp. 164199.

Telstra Corporation Limited (Telstra), Australian Council of Trade Unions (ACTU), Australian Communications. Electrical and Plumbing Union, Community and Public Sector Union, Association of Professional Engineers and Scientists Australia (2009) 'Telstra and communications industry unions agree on important principles', media release, 1 July.

\section{Authorial Details}

»Shaunnagh Dorsett is Associate Professor in Law at the University of Technology, Sydney. Email Shaunnagh.Dorsett@uts.edu.au.

» George Lafferty is Professor of Employment Relations in the School of Management at the University of Western Sydney, New South Wales. Email G.Lafferty@uws.edu.au. 